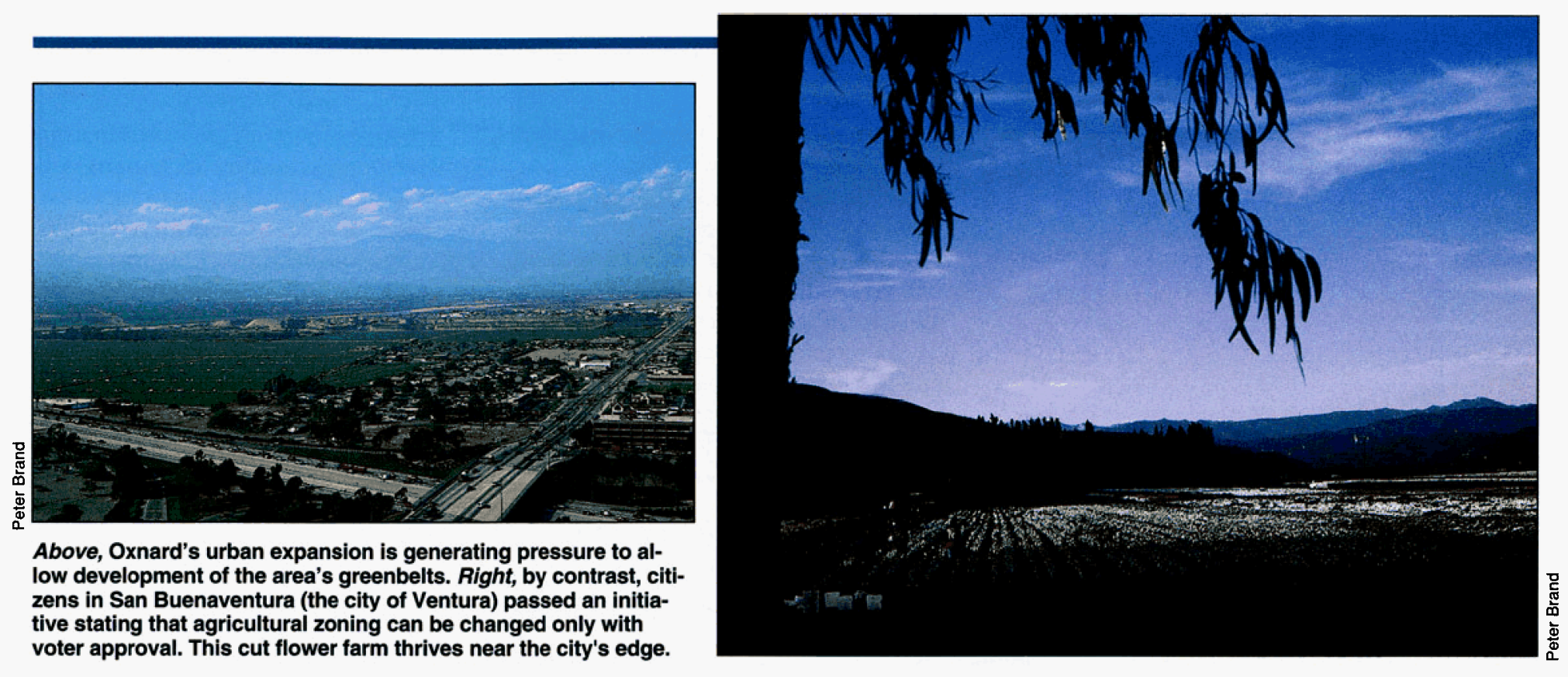

\title{
Permissive growth policies may encourage speculative investment in farmland
}

\author{
Michal C. Moore
} Agricultural land is at risk in much
of California, especially near the boundaries of rapidly growing communities. A study of five cities in Ventura County, which is roughly 60 miles east of Los Angeles, strongly suggests that traditional policies for protecting farmland may be ineffective. These policies exist in tension with tremendous growth pressure generated both by local economic development policies and by ur. ban expansion from the Los Angeles region. Development interests tend to bid on farmland in areas anticipated to be most susceptible to changes in land-use regulations.

While planners might believe that land market activities will be directed by farmland preservation policies, these policies are not always consistently applied by individual cities. And in municipalities that apply growth-control policies permissively, land speculators tend to bid up prices for parcels. In theory, greenbelts, the Williamson Act and spheres of influence protect agricultural land, sometimes in perpetuity. But a permissive approach toward development has encouraged speculators to bid up prices for "protected" land parcels in some areas. Land speculators may invest with the expectation of a return in a time period that is shorter than the expected life of the governing land-use plan. The power and preferences of the urban-conversion land market should not be ignored by local planners.

The impact of applying permissive growth-control policies on farmland near the urban edge is illustrated by the Ventura County land market. Ventura County has a rapidly increasing population as well as some of the most productive agricultural land in California, if not the world. Ventura County's microclimate and soils support a diverse range of crops from specialty fruits and nuts to double- and triple-row cropped vegetables. The more than 321,000 acres of farmland contribute more than $\$ 700$ million to the local economy annually. Each of the five major cities in the county (Camarillo, Fillmore, Oxnard, Santa Paula and Ventura) is essentially surrounded by agricultural land, and each acknowledges the need to conserve this valuable resource.

Ventura County is subject to a broad range of development proposals both because the area is desirable and because population growth spills over from the Los Angeles area. Between 1990 and 1995, the county's population and corresponding housing units increased $1.5 \%$ and $1.1 \%$, respectively. Accommodation of the new growth has typically occurred through annexation and development of agricultural land adjacent to cities rather than through redevelopment of existing urban areas.

The market for land is guided but not determined by planning policies, especially where speculative investments are concerned. Speculation in land parcels is based on expectations or "hopes" of development opportunities that are not specified in the gen- 




The study area included most of the south portion of Ventura County. Note the differences between the existing city boundaries (brown lines) and the spheres of influence (SOI) boundaries (red lines).

eral plan and that would typically generate higher future returns in the form of increased land value. Thus, land used for agriculture that is not presently available or zoned for development may still be subject to speculative bids designed to capture future values.

Land speculation is typically most prevalent in transitional or edge zones such as the urban/rural boundary. Speculative sales may involve a series of "strategic bids" by development interests on those areas anticipated to be most susceptible to changes within the controlling land-use regulations or plans. Anticipation of future bids may in turn presage requests for altering the basic municipal land-use plans, and may even precipitate changes in the plans themselves.

To protect farmland, Ventura County and each of the incorporated cities has created zoning designed to discourage the conversion of agricultural land to higher-intensity urban uses. Intensity denotes higher rent returns. In terms of investment, residential, industrial and commercial uses bring higher rent returns than agricultural uses. These policies, which include spheres of influence, are reinforced by the Local Agency Formation Commission (LAFCO), which has the power to grant or deny annexations to existing cities whether or not proper controls are maintained for agricultural land protection. In addition, the county has created long-term buffers to insulate

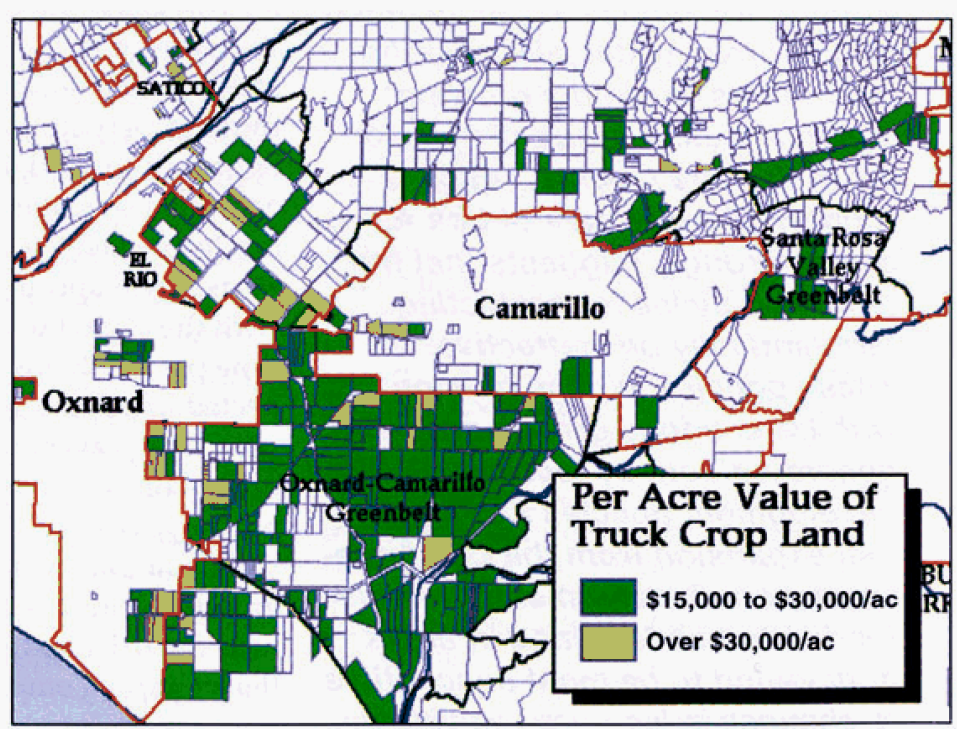

Speculative land purchases are shown in light green. The pattern clearly indicates that parcels just outside the spheres of influence (SOI), the red lines, are assumed to be developable in the future by those who purchased these parcels. Note also that these speculative parcels lie within a designated greenbelt, illustrating the ineffectiveness of this zoning. 
agriculture from urban pressure by designating greenbelts in cooperation with cities and by using the

Williamson Open Space Act, which reduces property taxes for farmers who commit to long-term agricultural use on their properties.

\section{Study data}

This study focused on agricultural land sale prices near Ventura County's five major cities (Camarillo, Fillmore, Oxnard, Santa Paula and Ventura) as well as near five designated greenbelt areas. We hypothesized that prices for farmland of similar quality and characteristics would be higher near communities that apply growth policies more permissively, even when the same policy tools are used.

To ascertain whether city planning policies influence adjacent land market behavior, we correlated land prices with the application of three key planning tools: sphere of influence boundaries, which are commonly applied and adjudicated by LAFCO; greenbelt designations entered into by two neighboring cities and the county; and farmland enrollment in the Williamson Act within designated greenbelts.

We studied 3,000 privately owned parcels in Ventura County that were larger than 1 acre and contained productive agriculture. We divided the parcels into four categories: parcels lying totally within incorporated city boundaries, parcels within adopted spheres of influence, parcels outside the sphere of influence but within an arbitrary buffer zone of about 1 / 4 mile, and parcels within designated greenbelts. We also determined the parcels' proximities to sphere of influence boundaries, to city boundaries and, when applicable, to greenbelt boundaries.

\section{Sphere of influence relationships}

Acting generally as an extension of the adopted urban limit line, sphere of influence boundaries are designed to limit municipal expansion to a zone established by LAFCO to represent 20 years of future growth. Sphere limit lines are tailored to each community and vary in terms of absolute distance. The spheres define areas within which development and conversion of farmland is expected to occur some day. Beyond the sphere boundary farmland is expected to be insulated from development pressure. Intense development requests beyond the sphere line are not typically approved unless (1) modification of the sphere boundary is approved by LAFCO; (2) annexation to an existing city is anticipated; or (3) prezoning is approved. We hypothesized that if spheres of influence actually protect farmland, there should be little difference in agricultural land prices regardless of how far the parcel is from the outer edge of the boundary.

However, the sphere of influence boundaries appear to have been interpreted differently from what planners intended. Initially, we established that within the spheres, the closer a parcel was to a city in Ventura County, the higher the price (fig. 1). These expected price increases indicated that sphere boundaries artifically extended the influence of urban boundaries.

We also compared the value of the cities' sphere of influence lands to that of county land outside the sphere boundaries. Since planning rules do not allow development in unincorporated areas, the low average price per acre of county land is assumed to reflect the true value of land used only for agricultural purposes. The data show that the average price increase for sphere of influence land ranged from nearly 1.5-fold in the city of Ventura to more than 3.5-fold in Oxnard compared to land prices outside the sphere boundary (fig. 2). The highest sphere of influence land values were in Oxnard and Camarillo, the cities with highest rates of growth and expansion. While the highest values tend to occur within sphere boundaries, Oxnard, Camarillo and Ventura (which is also growing fast) also have higher than average prices for farmland outside their spheres of influence (fig. 3).

The difference in land prices outward from city boundaries showed

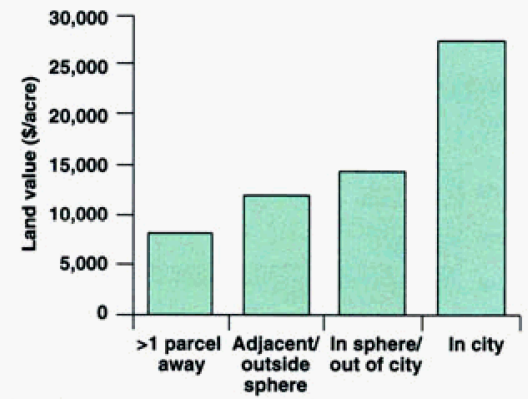

Fig. 1. Average of all city areas by sphere relationship in dollars per acre.

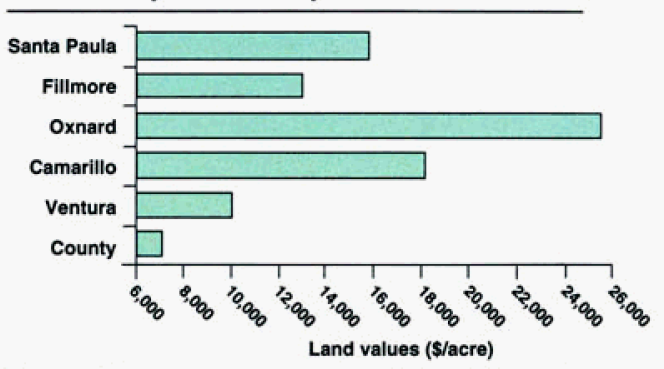

Fig. 2. Mean per acre land value within sphere but outside city boundaries. County land outside sphere of influence is the datum.

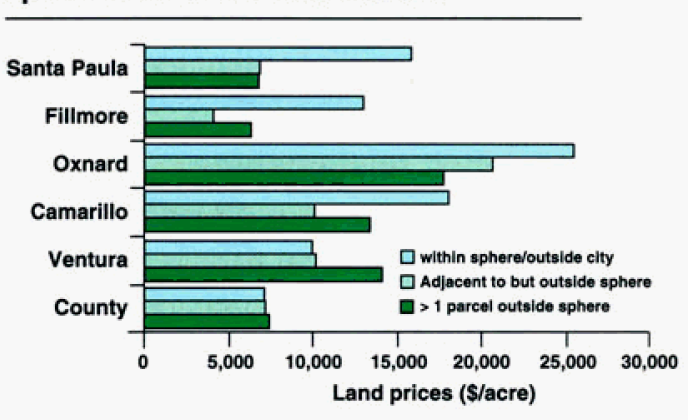

Fig. 3. Per acre land prices by city and greater county area with sphere of influence relationships.

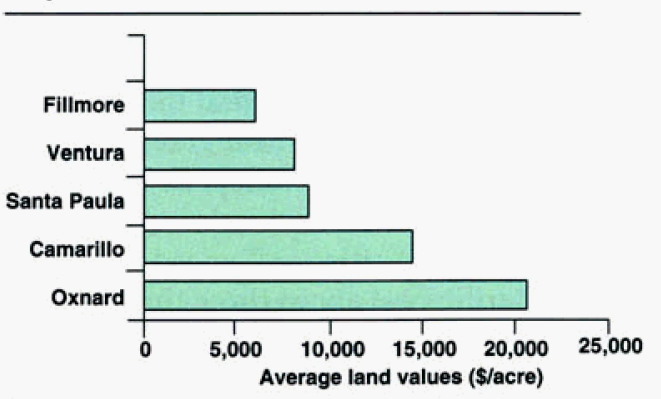

Fig. 4. Average per acre values for all greenbelt parcels by city proximity.

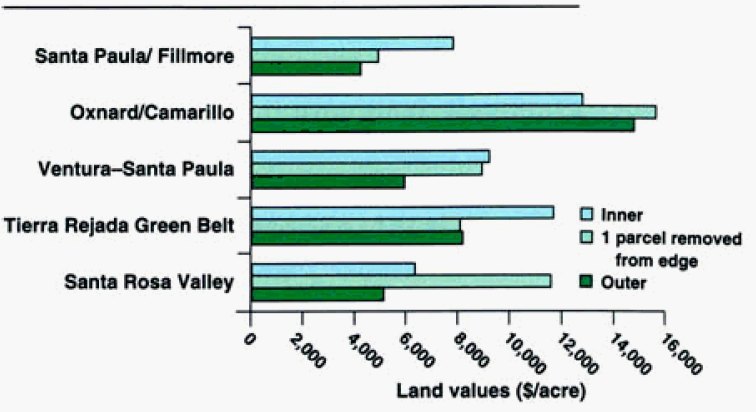

Fig. 5. Per acre values by greenbelt and by spatial location. 


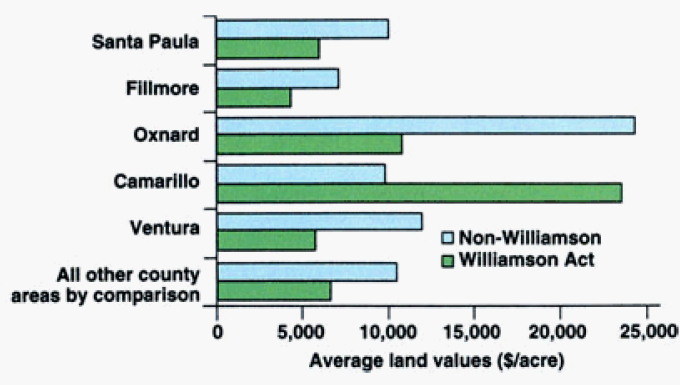

Fig. 6. Average per acre values in greenbelts by city proximity and Williamson Act contract.

higher land prices for similar types of parcels near urban areas with relatively permissive planning policy regimes. Thus, where more permissive planning policies are practiced, the sphere of influence boundary fails to provide a clear signal that development opportunities will not be allowed beyond the sphere boundary.

\section{Greenbelt relationships}

Local governments use greenbelts to buffer agricultural parcels from urban conversion. Often defensive in nature, greenbelts convey to the market that the public intends this area to remain in productive agriculture. However, if greenbelts do indeed protect farmland, land prices in different Ventura County greenbelts should be similar. However, this is not true in this case: the value of land in greenbelts is higher near cities with more permissive growth policies (fig. 4). Notably, greenbelt parcels between the fast-growing cities of Oxnard and Camarillo cost about three times more per acre than those near the slowergrowing city of Fillmore. This suggests that application of land-use policies for each city are weighed in the context of land market sales rather than the preservation intention of the greenbelt designation. In other words, the simple designation of greenbelt does not guarantee farmland protection.

There is more evidence that greenbelts do not protect farmland from speculation. If they did, then parcels on the outer edge and in the center of greenbelts should be priced similarly by the land market. However, the price of greenbelt parcels var- ies with their location in the greenbelt. The values tend to be depressed nearest to the urban area, suggesting there is some influence of urban externalities on land values even in a protected zone (fig. 5) One implication of this is that it may be necessary to provide buffer zones between urban expansion areas and greenbelts to minimize negative externalities such as air pollution and vandalism.

These results show that the market appears to be getting signals that land in certain greenbelts and in certain locations within a given greenbelt may be available for development or other use potential beyond strictly agricultural uses at some point in the future. Higher land prices will ultimately translate into lower rent for existing or future agricultural uses because returns from agricultural production may not offset increased land costs in the form of debt payments. Consequently there will be increased pressure for change of land use classifications. In other words, when an agricultural parcel brings lower rent, the landowner is likely to press to have the parcel rezoned so it can be sold at a profit.

\section{Williamson Act and greenbelts}

The Williamson Act is a contract arrangement with landowners and municipal governments designed to offer tax relief for landowners who commit to long-term agricultural use on their properties. The Act is intended to encourage landowners to plan for stable operations. If the Williamson Act actually does promote stability in agricultural operations, three things should be true: (1) there should be higher rates of Williamson Act contract enrollment within greenbelts, since the combination of a tax break and greenbelt should provide an extra incentive for landowners, by assuring them that they can farm there for the long term; (2) within a greenbelt area, there should be no significant price differential between parcels enrolled in the Williamson Act and those that are not; this is because the Act should offer similar incentives to landowners as greenbelts, assuming that the greenbelts are perceived to be relatively permanent so land speculators won't want to buy either type of property; and (3) prices for Williamson Act properties should be similar in different greenbelts as well as at different distances from the edge of a given greenbelt.

In fact, the results suggest the opposite, that Williamson Act enrollment does not protect farmland. We did not find the condition where every property or even the majority of properties within greenbelts were enrolled. There is a clear price difference between Williamson Act and non-Williamson Act properties within greenbelts: the price of the latter is higher (fig. 6). In the case of Oxnard, one of the least restrictive cities in terms of planning policy, non-Williamson Act properties cost more than twice as much as Williamson Act properties. This inflation of land value reinforces the perception that development opportunities will occur near Oxnard in the future. These results suggest that the Williamson Act contract does send a clear signal to the market that these properties are intended for long-term agricultural use.

Williamson Act properties in greenbelts are priced about the same regardless of which greenbelt they are in or where they are located in a given greenbelt.

Enrollment in the Williamson Act in the county generally appears to coincide with the perception that planning policies will remain in force at least until the end of the current contract period. However, given the relationship of agricultural zoning to contract enrollment, there appears to be a very weak link at best between Williamson Act enrollment of land and planning policies. The strongest motive for enrolling would seem to be a defensive statement on the part of the landowners who intend to maintain agricultural uses on their parcels rather than sell to land speculators. There does not appear to be a clear incentive to enroll in the Williamson Act in the vicinity of cities, especially those with high growth development activities. 


\section{Policies may be ignored}

This study suggests that the classic tools that California planners use to protect farmland may be only partially effective in deterring land speculators from buying agricultural land near cities. Policies designed to sustain and insulate viable agricultural zones (including spheres of influence boundaries, greenbelts and Williamson Act contracts) can have unanticipated outcomes when different cities apply them differently.

When cities tend to change zoning designations and planning restrictions, land speculators expect that given enough pressure, these policies will be altered in subsequent plan revisions. As a result, the speculative land market drives up the price of agricultural land near cities. One significant result of this is that farmland, traded for its agricultural production potential, cannot compete because the land is worth less when used for agriculture than for development.

The effectiveness of planning tools used by local communities needs to be re-examined: planners should develop alternative farmland protection policies that account for market forces. What we really need is a broad spectrum of new tools used in conjunction with zoning. This could include purchase or dedication of easements as well as more consistent application of zoning. What is missing is an appreciation of the fact that markets and market perception influences investment decisions. When the land market senses inconsistency or reversal of policy, speculations occurs, which spurs pressure to change plans. Without clear, consistently applied landuse policies, farmland will tend to act simply as a bank for future development opportunities.

M.C. Moore is a Ph.D. candidate, Department of Land Economy, University of Cambridge, England; and commissioner for the California Energy Commission, Sacramento.

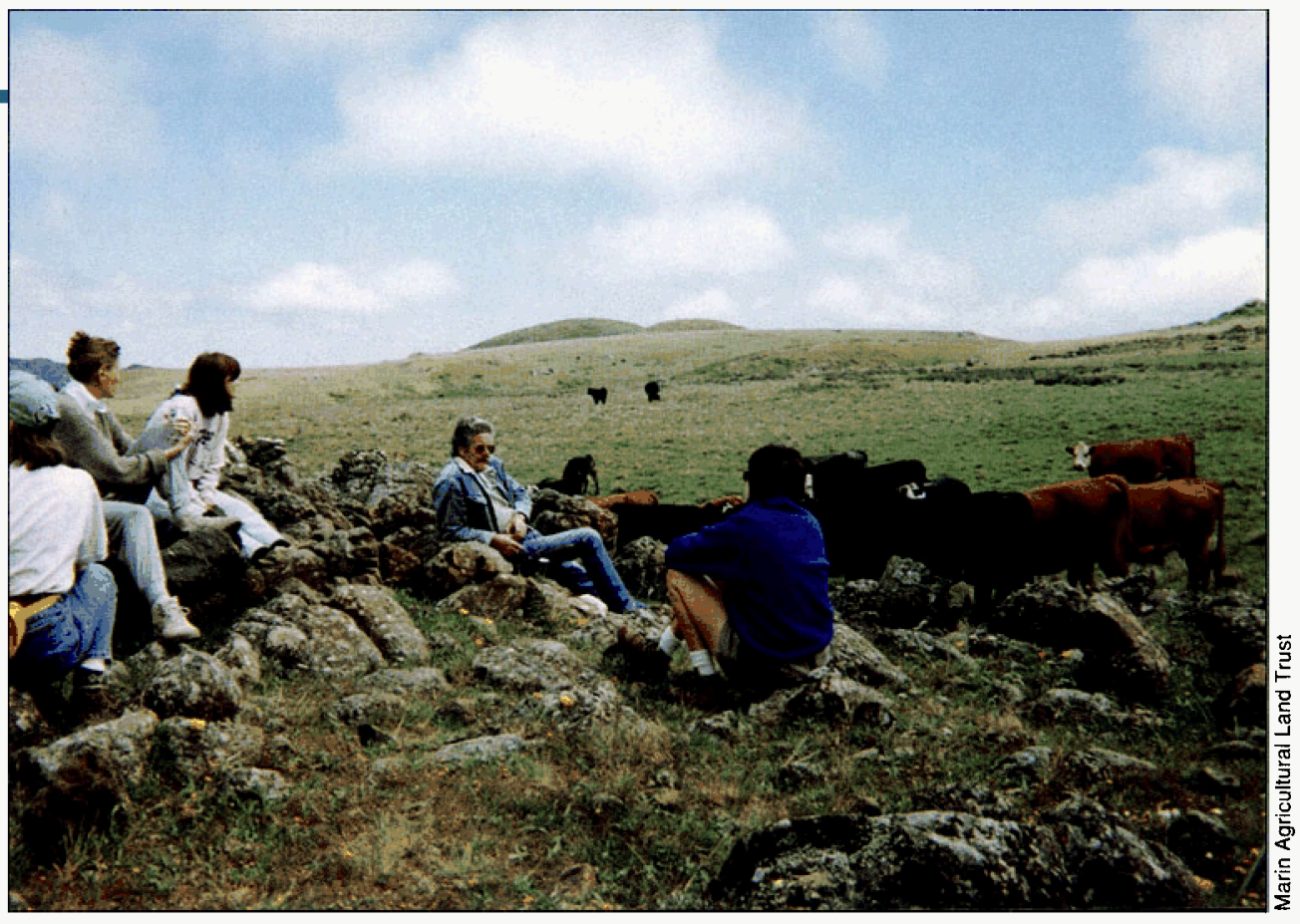

To promote public awareness of the importance of agriculture and the need to preserve it, the Marin Agricultural Land Trust gives tours of West Marin's farms and ranches. Rancher Richard Respini, center in blue jacket, talks to a tour group about the workings of his beef ranch, which is protected by a MALT agricultural conservation easement.

\section{Land trusts conserve California farmland}

Erik Vink

Communities can conserve farmland with land-use plans and zoning ordinances, but regulatory efforts are often transitory because future elected officials can revise them. To protect the land in the long term, agricultural land trusts work on a voluntary basis with individual landowners to acquire conservation easements that permanently restrict nonagricultural development of farmland. Farmers and ranchers are beginning to accept and support agricultural land trusts, which indicates that these trusts will continue to thrive.

A s the nation's top-producing agriAcultural state and also the fastestgrowing, California loses approximately 100,000 acres of agricultural land to urbanization annually. Because of the location of this growth, the state's best farmland is disproportionately affected, which has led to a strong public interest in protecting it.

Farmland conservation efforts have historically focused on land-use regulation by local governments. Local general plans and zoning ordinances have served to separate agricultural areas from incompatible land uses, such as urban uses where people congregate. While these regulatory efforts can be highly effective for a time, they are often transitory because the next group of elected officials can revise them.

The impermanence of regulatory efforts has led to a growing interest in efforts to protect farmland permanently. These efforts are carried out primarily by agricultural land trusts, which are private land conservation organizations. Agricultural land trusts work on a voluntary basis with individual landowners to acquire conser- 